INTERNATIONAL JOURNAL OF MULTIDISCIPLINARY RESEARCH AND ANALYSis

ISSN(print): 2643-9840, ISSN(online): 2643-9875

Volume 04 Issue 02 February 2021

DOI: 10.47191/ijmra/v4-i2-01, Impact Factor: 6.072

Page No.- 101-116

\title{
Antimicrobial, Antioxidant and Cytotoxic Activity of Green Synthesized Copper Nanoparticle of Parthenium Hysterophorus L.
}

\author{
Archana Rai ${ }^{1}$, Rohit Lall ${ }^{2}$ \\ 1,2 Department of Molecular and Cellular Engineering, Jacob School of Biotechnology and Bioengineering, \\ Sam Higginbottom University of Agriculture, Technology \& Sciences, Allahabad, India.
}

\begin{abstract}
Natural products are valuable and well known for their biological activities. In the current scenario, the research and analysis of plant leaf extract and nanoparticles synthesis with their biological activities has been expended significantly. For the synthesis of nanoparticles, Copper is the preferred metal among other metals due to its reported use in medical field as antimicrobial agents and its lethality. The aim of the present work is to assess antimicrobial and antioxidant activities of the methanolic leaf extracts and aqueous leaf extract mediated copper nanoparticles of Parthenium hysterophorus. Study also revealed the comparative analysis between methanolic leaf extracts and copper nanoparticles. Synthesis of copper nanoparticles (CUNPs) was confirmed by the change of color of aqueous extract, which were further confirmed by using UV-Vis spectrophotometer. The results indicated that copper nanoparticles have great antimicrobial activity against Bacillus subtilis, Staphylococcus aureus, Candida albicans and Aspergillus flavus rather than methanolic leaf extract. These studies confirmed that copper nanoparticles are capable to rendering high antimicrobial efficacy and hence has a great potential in the development of antimicrobial agents. Based on the DPPH, copper nanoparticles found to be good antioxidant when compared to methanolic leaf extract. Furthermore cells viability assay was also done against copper nanoparticles. These results concluded that copper nanoparticles are good source of therapeutic agent and applications of copper nanoparticles based on these findings may lead to valuable discoveries in various fields such as medical devices and antimicrobial systems.
\end{abstract}

KEYWORDS: Parthenium hysterophorus, Copper nanoparticles, antimicrobial activity, antioxidant activity, cell viability assay

\section{INTRODUCTION}

Parthenium hysterophorus L. (Asteraceae) is an aggressive annual herbaceous plant also known as Congress grass or Carrot weed and native to the Tropical America. It is now widely distributed in a number of tropical and sub-tropical countries (Gnanavel et al., 2013). In India, the weed has achieved major weed status already. It is very common along with the road sides, around the agricultural fields and on waste lands and considered as a noxious weed because of its prolific seed production and fast spreading ability, allelopathic effect on other plants, strong competitiveness with crops and health hazard to human as well as animals (Reviewed by Kaur et al., 2014). Phytochemistry of plant showed various toxic compounds such as Parthenin, Coronopilin, $2 \mathrm{~b}$ hydroxycoronophilin, Tetraneurin-A (Patel. Seema, 2011).The infestation of the weed causes yield losses up to $40 \%$ in several crops and reduces forage production by up to $90 \%$. The rapid spread of Parthenium in India would be a bigger risk to the expansion and sustainable production of many crops (Sushilkumar, 2014).

Control of Parthenium is therefore crucial to boost the productivity of agricultural crops in the country. It is reported that for better management of the weeds, knowing the habitat, morphology and biology of the weeds are also important. It can be kept control by enhancing its use in different aspects. Exploitation of the weed for the beneficial use should be promoted. The increased utilization of $P$. hysterophorus as insecticide, pesticide, and composite, raw material for biofuel and enzyme production can change the weed from a curse to a boon for civilization (Kaur et al., 2014). Antimicrobial and anticancerous nature of $P$.hysterophorus was reported already (Tapwal et al., 2011; Kumar et al., 2013).

Various researches in the field of antimicrobial development using nanoparticals are gaining interest as they can be used as an alternative to antibiotic (Ge et al., 2014). For the biosynthesis of nanoparticles, plant mediated approach is used now days which is a cost-effective and environmentally friendly alternative to chemical and physical methods (Niraimathi et al., 2013). 


\section{Antimicrobial, Antioxidant and Cytotoxic Activity of Green Synthesized Copper Nanoparticle of Parthenium Hysterophorus L.}

Considering the vast potentially of plants as a source for drug and its usefulness in the biosynthesis of metal nanoparticles, a systematic investigation was undertaken to screen a widespread available flora $P$. hysterophorus.

Natural products such as plant extracts provide unlimited opportunities for new drug discoveries (Sasidharan et al., 2011). Recent evidences from the pharmaceutical companies show that it still represent an extremely valuable chemical entities that can be used for the treatment of some complex diseases (Chin et al., 2006). These medicinal plants can be rich in phenolic compounds, alkaloids, diterpenoids, steroids and other compounds which inhibit the development of various microorganisms (Ranjitham et al., 2013). Besides this, phytochemicals in the plants extracts can act as reducing and capping agents in the reduction of metal ions to metal nanoparticles (Swarnalatha et al., 2013) and thus have found widespread use in the biosynthesis of metal nanoparticles which can be used in drug delivery (Doane and Burda, 2012), biosensing (Bedford et al., 2012), catalysis (An and Somerjai, 2012). Recently, the biosynthesis of metal nanoparticles using plants extracts has received considerable attention as a suitable alternative to existing synthesis of nanoparticles by chemical procedure and physical methods (Song and Kim, 2009; Chandran et al., 2006). It is also very cost effective (Sujitha and Kannan, 2013; Geethalakshmi and Sarada, 2012) and thereby it can be used as an economic and valuable substitute for the large scale production of metal nanoparticles.

Nanoparticles are small-sized materials of size range between 1-100 nm. These nanoparticles are more active and exhibited unexpected properties because of high surface to volume ratio and quantum size effect (Luo et al., 2005; Monga and pal, 2015). Furthermore for the agriculture purpose, nanoparticles of colloidal particulate include the size range between 10-1000 $\mathrm{nm}$. (Nakache et al., 1999).Copper is most widely used material in the world; it has various applications among a variety of metal particles such as gold, silver, iron, palladium, zinc etc. such as their electrical, optical, catalytic, biomedical and antimicrobial. The copper is highly toxic to microorganism such as bacteria (Escherichia Coli, Pseudomonas aeruginosa) whereas non-toxic to animal cells, due to these phenomena it is considered to be an effective antimicrobial metal (Pawar et al., 2014). Many researchers have reported the biosynthesis of metal nanoparticles by using various plants extracts (He et al., 2013, Niraimathi et al., 2013).

Considering the vast potentially of plants as a source for drug and its usefulness in the biosynthesis of metal nanoparticles, a systematic investigation was undertaken to screen a local flora, Parthenium hysterophorus.

Justification of the Work $P$. hysterophorus is most obnoxious exotic weed and widely spreading in all agro-climatic conditions of India; affecting agriculture, livestock health, human health, soil conditions, and native biodiversity. Concurrently it is neither traditionally nor commercially used in India. Since it is exerting broad spectrum allopathic effect over native plant biodiversity, therefore, this weed can kept control by enhancing its beneficial use should be promoted so that increased utilization can change the weed from a curse to a boon for civilization.

The present work is therefore justified in terms of the:

1. Addition of information regarding antimicrobial nature of $P$. hysterophorus.

The aim of the study is to assess the antimicrobial, antioxidant activity and cytotoxic effect of methanolic extract as well as copper nanoparticles from leaves of experimental plant $P$. hysterophorus.

\section{MATERIAL \& METHODS}

\subsection{Chemicals are Reagents}

All chemicals and reagents used in the experiment were analytical grade. Copper sulfate ( $\left.\mathrm{CuSO}_{4}\right)$ and 2,2-diphenyl-1-picrylhydrazyl (DPPH) were purchased from SRL, and used without further purification. For the preparation of chemicals and reagents Milli-Q water was used during the experiments. The bacterial and fungal strains were obtained from ABPL, Lucknow, Uttar Pradesh. Bacterial and fungal culture namely Bacillus subtilis, Staphylococcus aureus, Aspergillus flavus and Candida albicans were maintained in the respective medium.

\subsection{Collection of Plant Material Collection of Plant material and Preparation of sample}

Diseased free leaves of experimental plant PH will be collected from local areas of Allahabad, (U.P.) during the month of December. The raw material (leaves) will be carefully washed in order to remove dirt, dust and residues of the pesticide spray and dried under shade for $24 \mathrm{hrs}$. After that material will be dried at $550 \mathrm{C}$ in hot air oven for 4-5 days or until constant weight will be obtained and then ground in course powdered by electric grinding machine. Powdered material will be further passed from sieve \#20 and stored in air tight containers/desiccators until used. Powered plant material will be weighed and used for the preparation of aqueous and solvent extracts.

\subsection{Preparation of organic and inorganic extract}

The dried and powdered plant material (10gms) was extracted successively with $30 \mathrm{~mL}$ of methanol (organic) kept in refrigerator 


\section{Antimicrobial, Antioxidant and Cytotoxic Activity of Green Synthesized Copper Nanoparticle of Parthenium Hysterophorus L.}

for maceration and filtered with Whatman filter paper. The obtained extract was left in oven $\left(60^{\circ} \mathrm{C}\right)$ to evaporate. The dried extract was weighed (1gm.) and used for experiments. For the aqueous leaf extract (inorganic) (10gm) was weighed and added to $100 \mathrm{~mL}$ of Milli-Q water to make infusion filtered through Whatman No. 1 filter to obtain aqueous leaf extract used for synthesis of copper nanoparticles.

\section{Synthesis and Characterization of Copper Nanoparticles:}

Approximately $1 \mathrm{mM}$ copper sulfate $\left(\mathrm{CuSO}_{4} .5 \mathrm{H}_{2} \mathrm{O}\right)$ was used for the synthesis of $P$. hysterophorus -mediated copper nanoparticles synthesis. The syntheses of copper nanoparticles (CuNPs) $100 \mathrm{~mL}$ of aqueous leaf broth were added to $250 \mathrm{~mL}$ of aqueous copper sulfate solution in stirring condition. The concentration that gave the best results was further tested at room temperature and various time intervals. The reaction mixture was filtered through whatman filter paper for the extraction of Li-CuNPs. The residue was further purified by washing three times from distilled water to remove the water soluble biomolecules that were present. From this experiment, the best synthesis condition was established, and this condition was employed for the mass production of nanoparticles for further characterization and evaluation of their biological activities.

\section{Characterization of synthesized nanoparticles:}

The plant leaf mediated copper nanoparticles were characterized by commonly two method namely visual inspection and UV-Vis spectra analysis.

Visual Inspection: The bio-reduction of copper nanoparticles using aqueous extract of leaf observed by change of the aqueous leaf extracts color and exhibit turbid indication.

\subsection{UV-Vis spectra analysis}

The reduction of copper sulfate to copper using aqueous extract was monitored by measuring the UV-Vis spectrum at the range of 250-750 nm. The reaction mixture was initially diluted and aliquation was done with milli-Q water. Later the measurements of turbidity were recorded on double beam spectrophotometer (Labornics-Model CT-2800) at time interval of 3hrs and 24hrs.

\subsection{Evaluating Of Biological Activities}

\section{Antibacterial Screening}

The initial determination of the antibacterial activity, agar well diffusion was performed ( $\mathrm{Naz}$ and Bano, 2013). The antimicrobials present in the plant extract and copper nanoparticles are allowed to diffuse out into the medium and interacted in a plate freshly seeded with the test bacteria on LB agar medium. The resulting zone of inhibition measured in millimeters.

The confirmatory assay called as antibacterial kill-kinetic assay was used to determine the bactericidal activity of methanolic leaf extract and copper nanoparticles. According to standard guide for assessment of antimicrobial activity using growth kinetics procedure with some modifications (Antimicrobial Susceptibility Testing Method, 2008), time- kill kinetics of the sample on test bacteria were carried out to assess the killing rate of the extract within a given contact time.

\subsection{Antifungal Analysis}

Antifungal screening was carried out using disc diffusion method Kirby-Bauer (1966). Petri plates were prepared with $20 \mathrm{~mL}$ of sterile Potato-Dextrose agar (PDA). The test culture were swabbed on the top of the solidified media and allowed to dry for $15 \mathrm{~min}$. Different amount $(5 \mu \mathrm{L}, 10 \mu \mathrm{L}, 15 \mu \mathrm{L}, 20 \mu \mathrm{L}, 25 \mu \mathrm{L}$ and $50 \mu \mathrm{L}$ from $100 \mu \mathrm{g} / \mathrm{mL}$ ) of methanolic leaf extract and CuNPs. The loaded discs were placed on the surface of the medium and left for $30 \mathrm{~min}$ at room temperature. The plates were incubated for $48-72 \mathrm{~h}$ at $28^{\circ} \mathrm{C}$ for fungal growth. Zone of inhibition were recorded in millimeters, the fungal strains were Aspergillus flavus and Candida albicans. Streptomycin used as positive control drug and DMSO was used as negative control for antifungal screening. Experimental results were given as mean \pm S.D. of the two parallel measurements.

\subsection{Antioxidant Activity}

The antioxidant activity of the extracts was evaluated by DPPH radical scavenging assay which was originally described by Blois (1958). In brief, $0.1 \mathrm{mM}$ DPPH in $95 \%$ ethanol was prepared. This solution $(1 \mathrm{~mL}$ ) was added to $3 \mathrm{~mL}$ of sample (methanolic leaf extract and copper nanoparticles) in ethanol at a concentration $(100 \mu \mathrm{g} / \mathrm{mL})$. The mixture was shaken vigorously and allowed to stand at room temperature for $30 \mathrm{~min}$. Then, absorbance was measured at $517 \mathrm{~nm}$ by using UV-Vis spectrophotometer. Reference standard compound being used was ascorbic acid and experiment was done in triplicate (Patel and Patel, 2011). Lower absorbance of the reaction mixture indicated higher free radical scavenging activity (Koleva et al., 2002). The percentage DPPH scavenging effect was calculated by using following equation:

DPPH scavenging effect (\%) or Percent inhibition $=A_{0}-A_{1} / A_{0} \times 100$. 


\section{Antimicrobial, Antioxidant and Cytotoxic Activity of Green Synthesized Copper Nanoparticle of Parthenium Hysterophorus L.}

Where $A_{0}$ was the Absorbance of control reaction and $A_{1}$ was the Absorbance in presence of test or standard sample (Achola et al., 1998).

\subsection{Cell Viability Assay}

In order to assess the activity of copper nanoparticles against mouse macrophage cell line J-774A.1, was used. The cell viability was determined with 3-(4,5-dimethyl-2-thiazolyl)-2,5-diphenyl-2H-tetrazolium bromide (MTT) assay (Mosmann, 1983) and some modification (Ahmad et al., 2011; Loisean et al., 2011). Exponentially growing cells J774.A-1 (Mouse macrophage) ( $1 \times 10^{4}$ cells $/ 100 \mu \mathrm{l} /$ well) are incubated in RPMI-1640 containing 10\% FBS with different sample concentrations $(30-100 \mu \mathrm{g} / \mathrm{ml})$ for $72 \mathrm{hours}$ and are incubated at $37 \circ \mathrm{C}$ in a humidified mixture of $\mathrm{CO}_{2}$ and $95 \%$ air in an incubator. Stock solutions of compounds are initially dissolved in DMSO and further diluted two fold with fresh complete medium. After incubation, $25 \mu \mathrm{l}$ of MTT reagent (5mg/ml) in PBS medium, followed by syringe filtration, was added to each well and incubated at $37^{\circ} \mathrm{C}$ for 2 hours. At the end of the incubation period, the supernatant is removed by tilting plate completely without disturbing cell layer and $150 \mu$ l of pure DMSO are added to each well. After $15 \mathrm{~min}$. of shaking, the readings are recorded as absorbance at $544 \mathrm{~nm}$ on a micro plate reader. The cytotoxic effect are expressed as $50 \%$ cytotoxic concentration, i.e., as the concentration of a compound which provoked a $50 \%$ reduction in cell viability compared to cell in culture medium alone.

\subsection{Biochemical Studies}

The prepared leaf sample of test plant was used for the determination of total carbohydrate by colorimetric method using anthrone, (Morris, 1948). The water soluble protein was estimated by following the method of Lowry et al. (1951).

\section{RESULTS AND DISCUSSION}

\subsection{Characterization of Copper Nanoparticles}

\subsubsection{Visual Inspection}

During the biosynthesis, formation of nanoparticles was indicated by the change in color of the mixture (copper sulphate and leaf extract). After reaction, turbidity exhibited and the reaction mixture changed its color from intense green to brown color indicating the synthesis of $\mathrm{Cu}$ nanoparticles due the reduction of cupric $(\mathrm{Cu}+)$ ions and due to the excitation of surface plasmon vibration in metal nanoparticles.

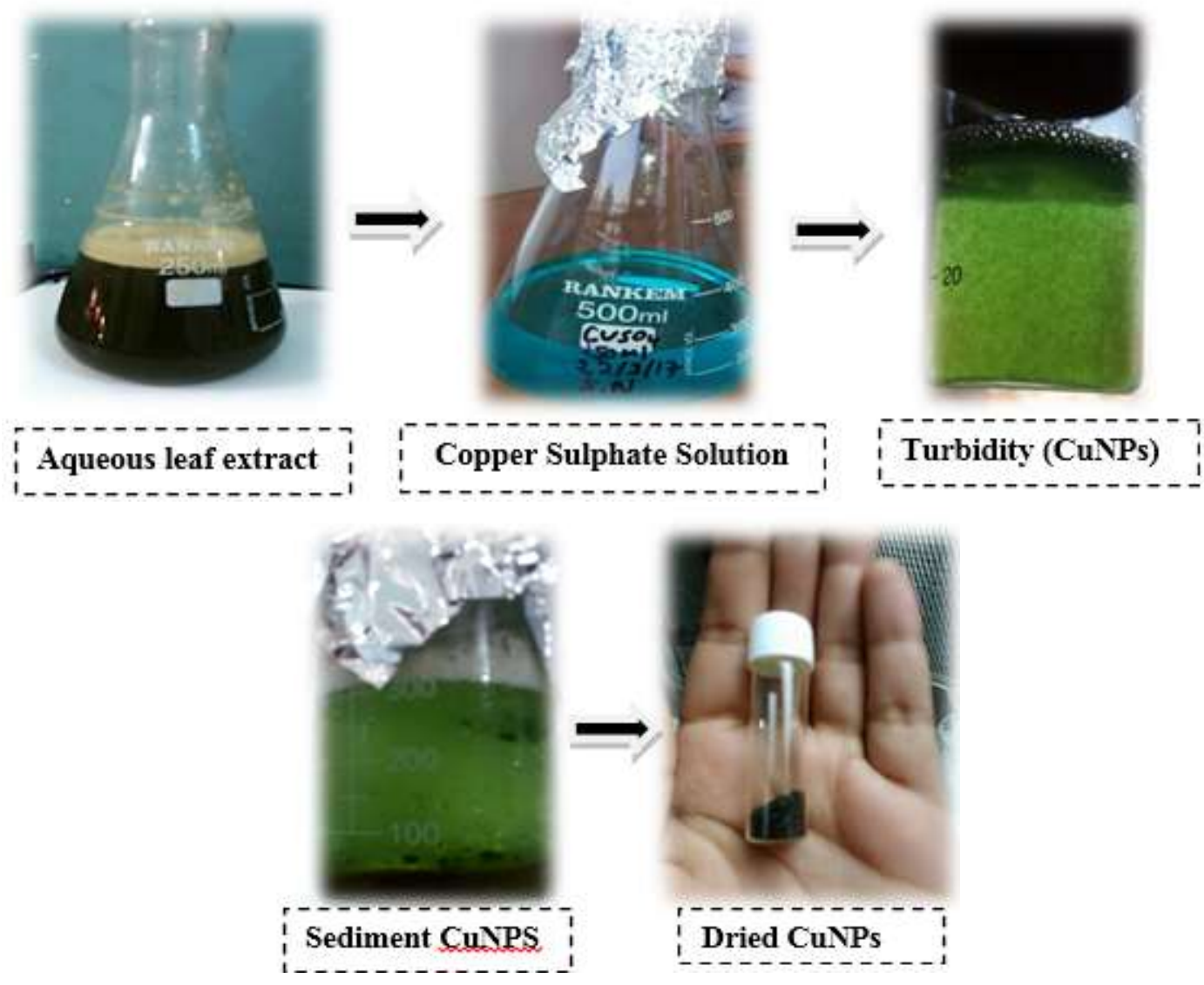

Figure 1: Visual Inspection of CuNPs 


\section{Antimicrobial, Antioxidant and Cytotoxic Activity of Green Synthesized Copper Nanoparticle of Parthenium Hysterophorus L.}

\subsubsection{UV-Vis Spectra Analysis}

UV-Visible absorption spectrum is the preliminary characterization to know the absorbance of synthesized nanoparticles. The results obtained from UV-Vis spectra analysis of the nanoparticles sample. It is the most important method of analysis to detect the Surface Plasmon Resonance property of CuNPs (Curtis et al., 1998). Absorption spectrum of the prepared copper nanoparticles were taken in different time intervals up to $24 \mathrm{hrs}$ from the reaction mixture, in the range of $250-750 \mathrm{~nm}$ by using double beam Spectrophotometer (Labronics-Model CT-2800). The CuNPs formation was confirmed from the peak around 450 to $550 \mathrm{~nm}$. The peak value was found to be gradually decreased with increase in particle size. Copper SPR effects decrease with the time because of the oxidation of the synthesized copper nanoparticles (Tilaki et al., 2007).

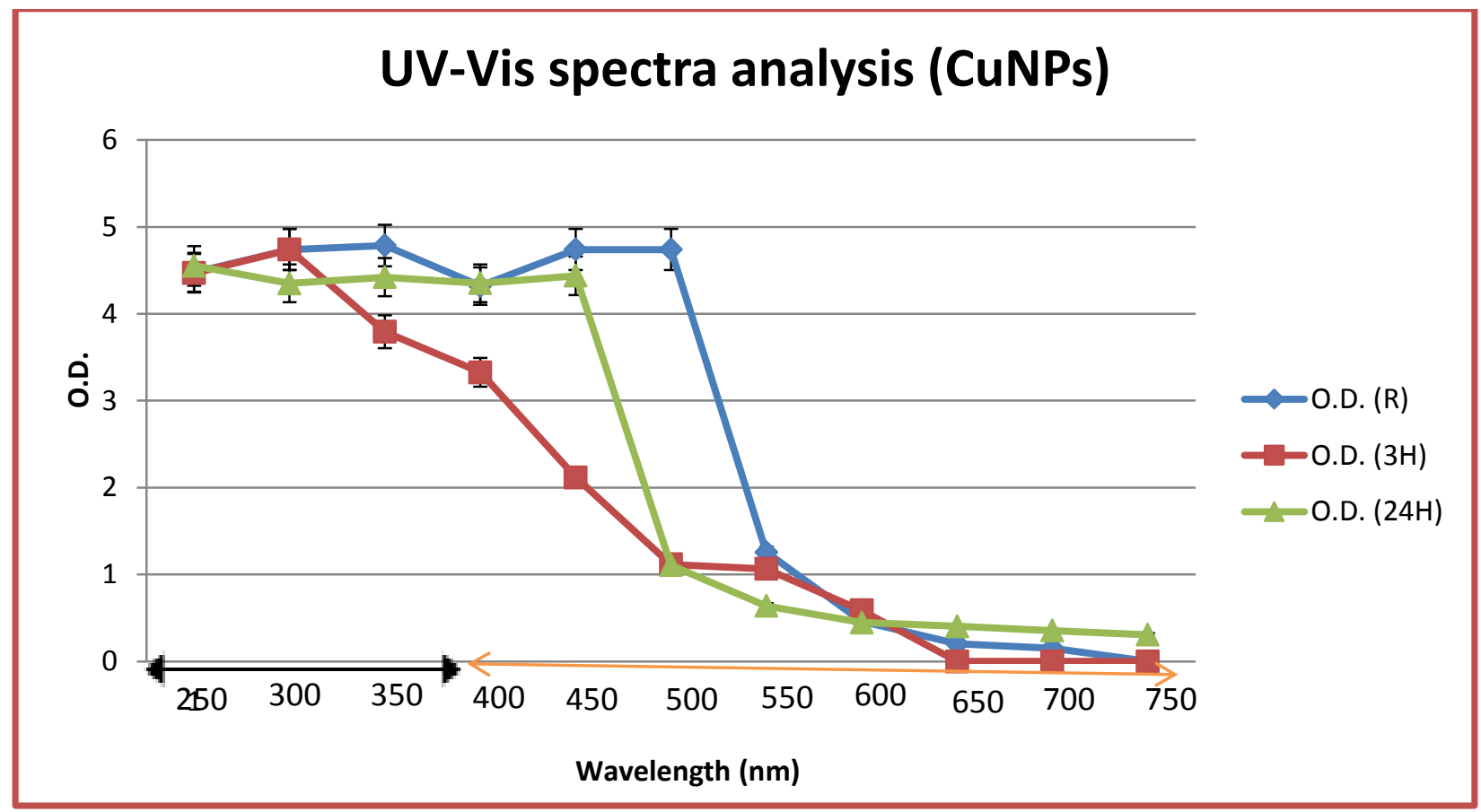

Figure 2: UV-Vis absorption spectra analysis

Where, $R=$ Reference (Aqueous leaf extract)

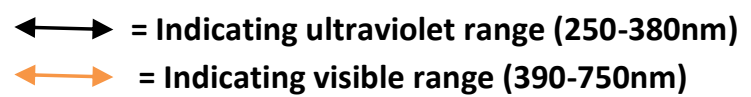

\subsection{Antibacterial Activity}

The antibacterial results of the nanomaterial were compared to the metal free $P$. hysterophorus methanolic leaf extract. At a concentration of $100 \mu \mathrm{g} / \mathrm{mL}$ in DMSO (as a diluent), the LI-CuNPs were active to both gram positive bacterial strains (Bacillus subtilis \& Staphylococcus) used for the antibacterial screening. The nanoparticles showed greater antibacterial activity compared to plant extract of methanolic leaf extract of experimental plant. The enhanced antibacterial activity of the CuNPs could be attributed to their liposolubility. This is because, according to Overtone's concept of cell permeability, the lipid membrane that surrounds the microbial cell favours the passage of only the lipid-soluble substances. Hence lipophilicity is a major property for antibiotics. In addition, Tweedy's chelation theory proposed that on chelation of metal ions by ligands (constituent of plant extract) causes the polarity of the metal ion to be reduced to a greater extent due to the orbital overlap (between the metal and ligand orbitals) and partial sharing of the positive charge of the metal ion with donor groups of the ligands. This increases the delocalization of $\pi$ electrons over the whole chelate ring and enhances the lipophilicity of the metal complexes. The increased lipophilicity enhances the penetration of the metal complexes through lipid membranes thereby blocking the metal binding sites in the enzymes of microorganisms. In addition, it disturbs the respiration process of the cell and blocks the synthesis of the proteins, thereby, restricts further growth of the organism (Dharamraj et al., 2001). Methanolic leaf extract was most active against Bacillus subtilis and did not show any effective activity against Staphylococcus aureus. The results clearly showed that antibacterial activity of nanoparticles cannot be credited to the nature of plant extract and $\mathrm{CuSO}_{4} .5 \mathrm{H}_{2} \mathrm{O}$ individually as the $\mathrm{LI}$-CuNPs showed greater activity compared to them. Moreover, the antibacterial activity of the copper nanoparticles also be attributed to presence of some phytochemical constituents of the leaf extract (Elemike et al., 2017). The antibacterial activity result was shown in Table 1. 
Antimicrobial, Antioxidant and Cytotoxic Activity of Green Synthesized Copper Nanoparticle of Parthenium Hysterophorus L.

The antibacterial potential of the methanolic leaf extract and copper nanoparticles were further confirmed at different concentrations in order to determine the complete inhibition of the samples for the bacterial strains by antibacterial kill kinetic assay. Figure 3 showed the antibacterial kill kinetics of copper nanoparticles against $B$. subtilis and $S$. aureus.

Table 1: Antibacterial activities of Methanolic leaf extract \& Copper nanoparticles

\begin{tabular}{|c|c|c|c|c|}
\hline \multirow[t]{3}{*}{ S. No. } & \multirow[t]{3}{*}{ Organism } & \multirow{3}{*}{$\begin{array}{l}\text { Concentration of } \\
\text { the sample } \\
(\mu \mathrm{L} / \text { well) }\end{array}$} & \multicolumn{2}{|c|}{ Zone of inhibition $(\mathrm{mm})$ Mean \pm S.D. } \\
\hline & & & & \\
\hline & & & $\begin{array}{l}\text { Methanolic leaf extract } \\
(100 \mu \mathrm{g} / \mathrm{mL})\end{array}$ & $\begin{array}{l}\text { CuNPs } \\
(100 \mu \mathrm{g} / \mathrm{mL})\end{array}$ \\
\hline \multirow{6}{*}{1.} & \multirow{6}{*}{ Bacillus subtilis } & 5 & $9.66 \pm 0.57$ & $18.33 \pm 0.57$ \\
\hline & & 10 & $15.66 \pm 0.57$ & $23 \pm 1.00$ \\
\hline & & 15 & $24.33 \pm 1.15$ & $25 \pm 1.00$ \\
\hline & & 20 & $31 \pm 1.00$ & $29.66 \pm 0.47$ \\
\hline & & 25 & $35 \pm 1.00$ & $34.66 \pm 0.577$ \\
\hline & & 50 & $44 \pm 1.73$ & $46.33 \pm 1.52$ \\
\hline \multirow{6}{*}{2.} & \multirow{6}{*}{ Staphylococcus aureus } & 5 & - & $7.66 \pm 0.577$ \\
\hline & & 10 & - & $14 \pm 1.73$ \\
\hline & & 15 & - & $20.33 \pm 0.577$ \\
\hline & & 20 & - & $22 \pm 1.73$ \\
\hline & & 25 & - & $29.33 \pm 0.94$ \\
\hline & & 50 & - & $35.33 \pm 0.57$ \\
\hline
\end{tabular}

Note: Diameter $(\mathrm{mm})$ of zone of inhibition ( mean \pm S.D.)

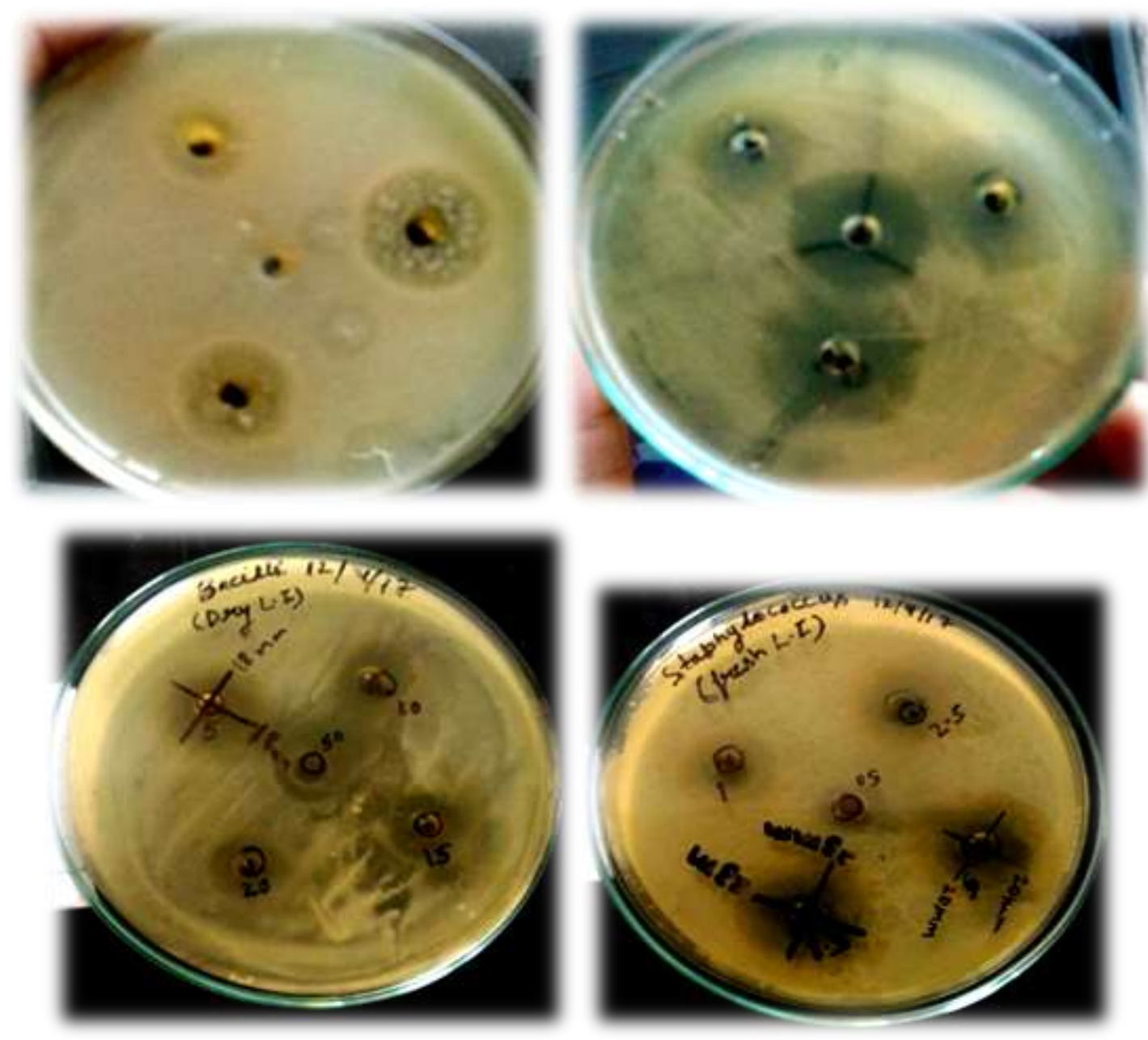

Figure 3: Antibacterial effect of Methanolic extract \& CuNPs 


\section{Antimicrobial, Antioxidant and Cytotoxic Activity of Green Synthesized Copper Nanoparticle of Parthenium}

Hysterophorus L.

Plate A- showing antibacterial effect of methanolic extract of leaf against Bacillus subtilis at 5, $10 \& 15 \mu \mathrm{L}$ along with negative control DMSO $(50 \mu \mathrm{L})$.

Plate B - Showing antibacterial effect of methanolic extract against B. subtilis at 20, 25 and $50 \mu \mathrm{L}$ along with positive control Streptomycin $(4 \mathrm{mg} / \mathrm{mL})$.

Plate C - Showing antibacterial effect of aqueous leaf extract mediated copper nanoparticles against $B$. subtilis at 5, 10, 15 and $20 \mu \mathrm{L}$.

Plate D- Showing antibacterial effect of CuNPs against Staphylococcus aureus at 5, 10,

$15 \mu \mathrm{g} / \mathrm{mL}$.

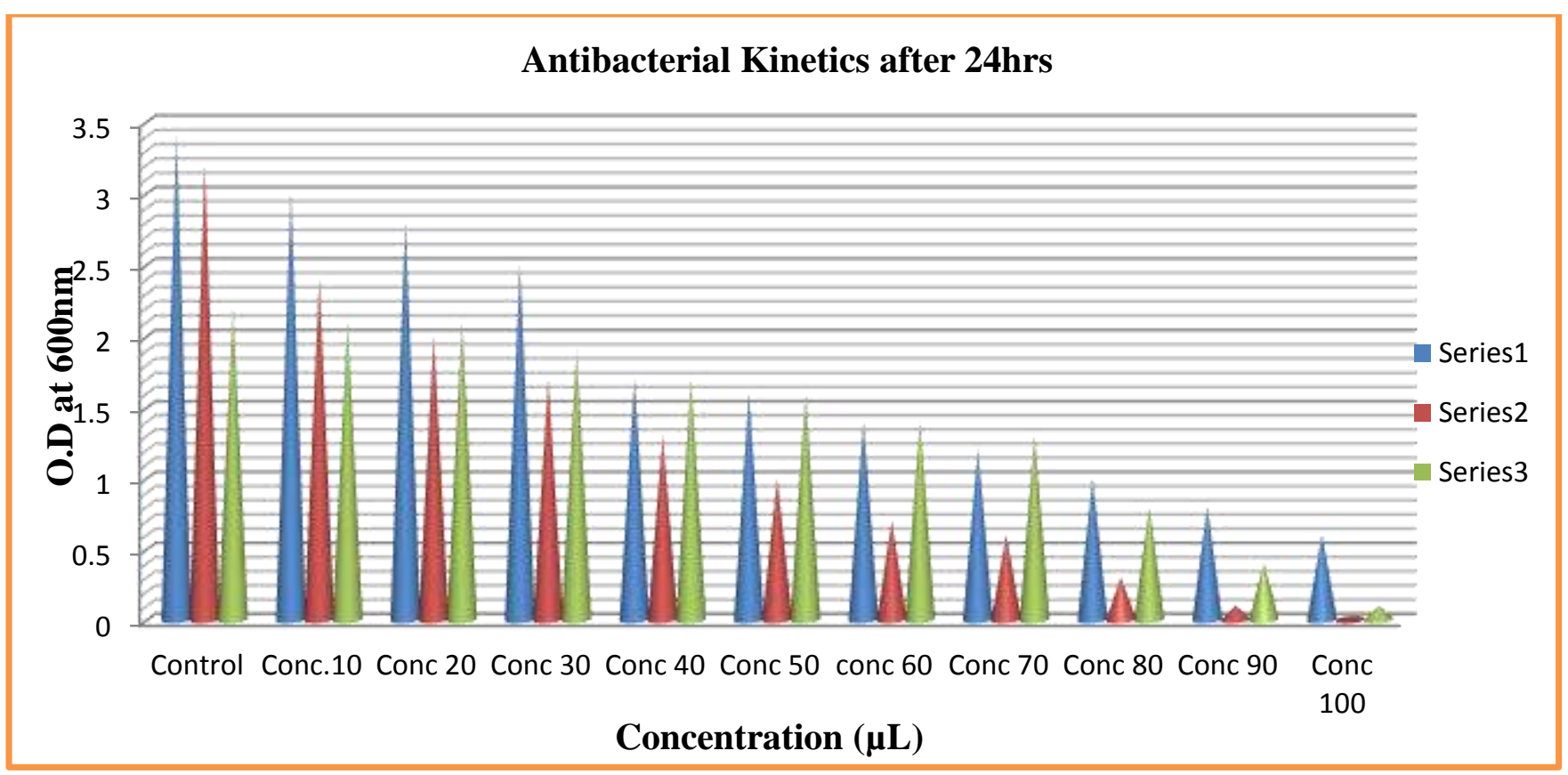

Figure 4: Antibacterial Kinetics after 24 hrs incubation

Series 1: Methanolic leaf extracts (B. subtilis)

Series 2: CuNPs (B. subtilis)

Series 3: CuNPs (S. aureus)

\subsection{Antifungal activity (Disc Diffusion method}

Methanolic leaf extract was found efficient to inhibit fungus $C$. albicans while it did not show any activity against $A$. flavus. Whereas, the aqueous leaf extract mediated copper nanoparticles displayed antifungal activity toward the tested pathogenic strains of $A$. flavus and $C$. albicans, respectively. A. flavus depicted the highest sensitivity to nanoparticles compared to the $C$. albicans and was more adversely affected by the copper nanoparticles. These revealed that both methanolic leaf extract and copper nanoparticles have potential to inhibit pathogenic fungi but photosynthesized copper nanoparticles had more influence to reduce the microorganisms.

Table 4: Antifungal activity of Methanolic leaf extract and CuNPs

\begin{tabular}{|c|c|c|c|c|}
\hline \multirow[t]{2}{*}{ S.No. } & \multirow[t]{2}{*}{ Organism } & \multirow[t]{2}{*}{$\begin{array}{l}\text { Concentration of the sample } \\
\text { ( } \mu \mathrm{L} / \mathrm{Disc})\end{array}$} & \multicolumn{2}{|c|}{$\begin{array}{l}\text { Zone of inhibition }(\mathrm{mm}) \\
\text { Mean } \pm \text { S.D. }\end{array}$} \\
\hline & & & $\begin{array}{l}\text { Methanolic } \\
\text { extract }\end{array}$ & CuNPs \\
\hline \multirow{6}{*}{1.} & & 5 & - & $17.66 \pm 0.57$ \\
\hline & & 10 & - & $26.66 \pm 0.57$ \\
\hline & Aspergillus flavus & 15 & - & $29.66 \pm 0.57$ \\
\hline & & 20 & - & $35.33 \pm 0.57$ \\
\hline & & 25 & - & $37.66 \pm 0.57$ \\
\hline & & 50 & - & $42.66 \pm 0.57$ \\
\hline
\end{tabular}


Antimicrobial, Antioxidant and Cytotoxic Activity of Green Synthesized Copper Nanoparticle of Parthenium Hysterophorus L.

\begin{tabular}{lll|l|}
\hline & 5 & $9 \pm 1$ & $1 \pm 0$ \\
\hline & 10 & $13.66 \pm 1.52$ & $12.66 \pm 0.57$ \\
\hline \multirow{2}{*}{ Candida albicans } & 15 & $15.66 \pm 0.57$ & $22.66 \pm 0.57$ \\
& 20 & $19.66 \pm 0.57$ & $29.66 \pm 0.57$ \\
& 25 & $24.33 \pm 0.57$ & $31 \pm 1$ \\
\hline & 50 & $35.33 \pm 0.57$ & $35.33 \pm 0.57$ \\
\hline
\end{tabular}

Note: Diameter $(\mathrm{mm})$ of zone of inhibition (mean \pm S.D.)
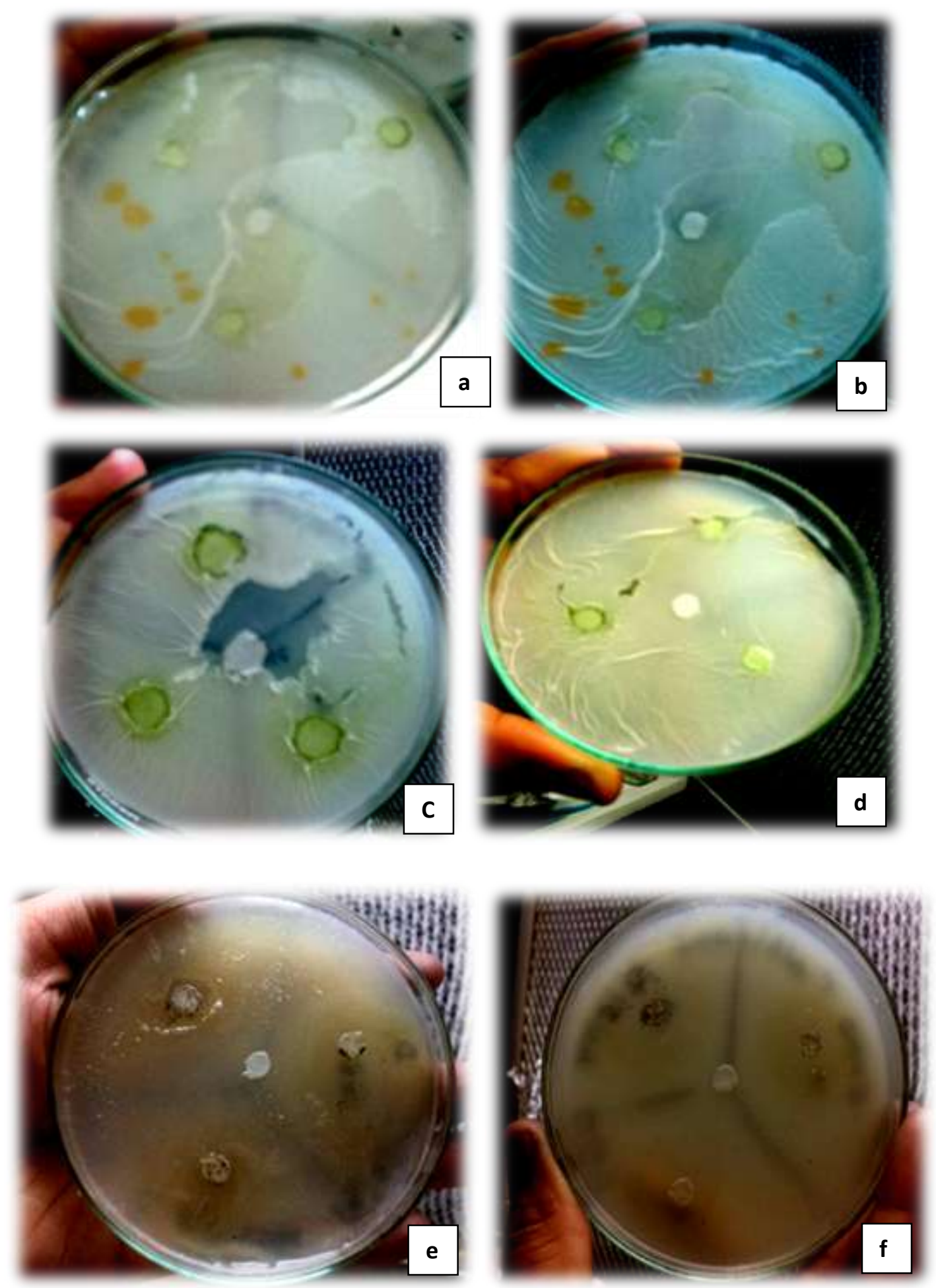
Antimicrobial, Antioxidant and Cytotoxic Activity of Green Synthesized Copper Nanoparticle of Parthenium Hysterophorus L.

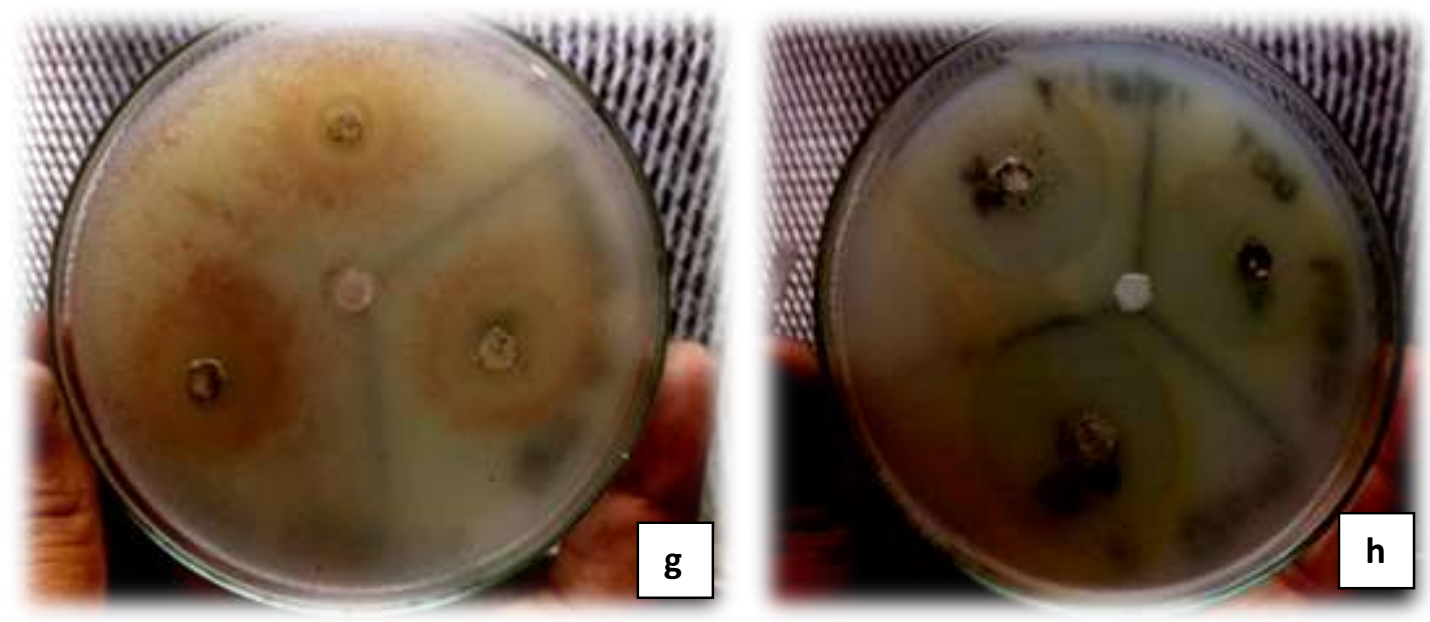

Figure 5: Antifungal effect of Methanolic extract \& CuNPs

Plate a \& b - Showing antifungal effects of methanolic leaf extract against Candida albicans

Plate c \& d-Showing methanolic extract inhibition effect against Aspergillus flavus, there was no inhibition zone found around the extract but positive control (Streptomycin) inhibited test fungi.

Plate e \& f-Showing antifungal activity of copper nanoparticles against $C$. albicans at different concentrations.

Plate $\mathbf{g} \& \mathbf{h}$ - Showing antifungal effect of copper nanoparticles against $A$. flavus at different concentration.

\section{Antioxidant activity}

Antioxidant activity refers to the inhibition of oxidation of molecules by inhibiting the initiation step of the oxidative chain reaction and formation of stable radicals, which are non-reactive. Plant contains phytochemicals, vitamins and other nutrients, which possesses strong antioxidant activity and helped in protecting cells against oxidative stress caused by free radicals (Mittle et al., 2014). Termination of free radicals in cells prevents the pathologically disorders like cancer, heart attacks etc. (Kumar et al., 2016). Antioxidant activity of both methanolic leaf extract and copper nanoparticles were carried out by DPPH assay by using ascorbic acid as standard. DPPH is a purple colored stable radical of organic nitrogen with a maximum absorbance at $517 \mathrm{~nm}$ and it is widely used to study radical scavenging activities of extracts and pure compounds. When odd electron becomes paired off in the presence of a free radical scavenger to form hydrazine, the absorption reduces and the DPPH solution is decolorized from deep violet to light yellow. The degree of reduction in absorbance measurement is indicative of the radical scavenging (antioxidant) power of the methanolic extract and copper nanoparticles (Pham et al., 2008).

From the result, the copper nanoparticles found to be more antioxidant capacity (67\%) rather than plant methanolic leaf extract (28.82\%) and standard ascorbic acid (44.85\%). The results signified that copper nanoparticles can be effective antioxidant agent. It is predicted that higher antioxidant activity of nanoparticles is might be due to encapsulation of bioactive molecules on the surface of CuNPs through the electrostatic attraction between negatively charged bioactive compounds $\left(\mathrm{COO}^{-}, \mathrm{O}^{-}\right)$and neutral or positively charged nanoparticles (Du et al., 2013; Kumar et al., 2016).

Table 5: Percentage inhibition of DPPH free radical scavenging

Sample Concentration of \% Inhibition of DPPH free radical scavenging activity at $517 \mathrm{~nm}$ sample $(\mathrm{mg} / \mathrm{mL})$

\begin{tabular}{l|l|l}
\hline \multicolumn{1}{c}{ Reference } & 0.2 & 44.85 \\
\hline MeOH extract & 0.1 & 28.82 \\
\hline CuNPs & 0.1 & 67 \\
\hline
\end{tabular}




\section{DPPH free radical scavenging activity}

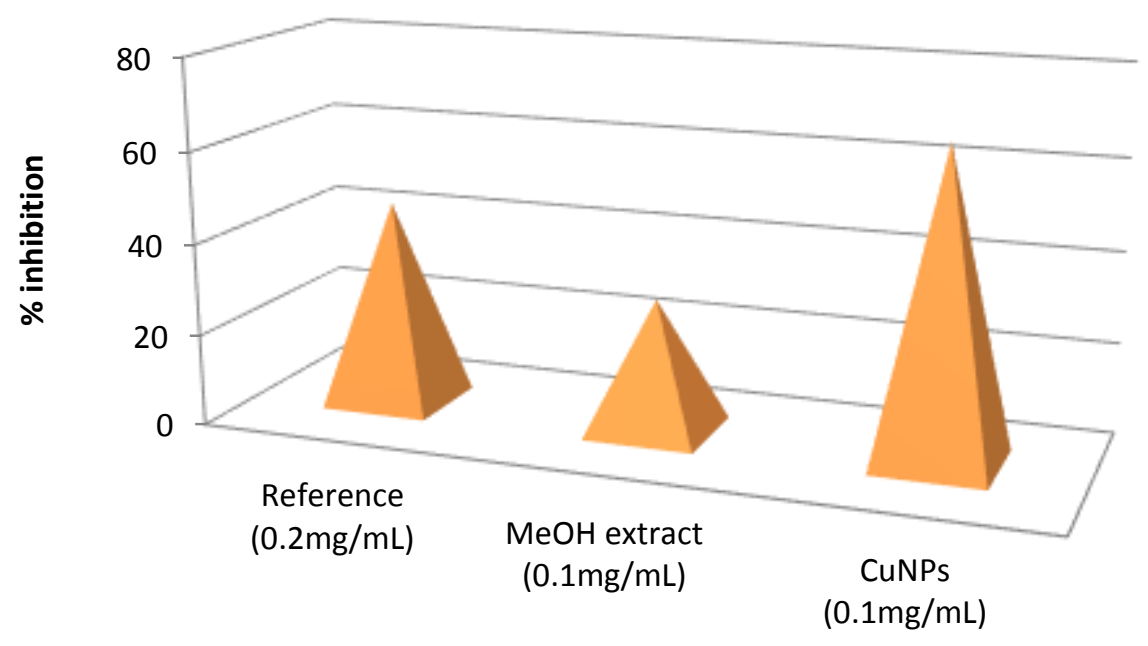

Figure 6: Percentage inhibition of antioxidant capacity

\section{Cytotoxic activity of copper nanoparticles}

Mouse macrophages cell line culture was used to demonstrate copper nanoparticles cytotoxicity as measured by the MTT assay. It is worth emphasizing that MTT assay reflects only the changes in mitochondrial function, and is not indicative of the manner or stages of cell death (Ahmad et al., 2010; Rocchetta et al., 2006; Cui Y et al., 2014; Dan et al., 2013; Qi et al., 2013; Vera and Migaud, 2009; Singh 2007 and Niska et al., 2015). Niska et al. (2015) reported that a reduction in the amount of formazon produced MTT can be proportional to the cell number. In the present study, the proportional of viable cells declined after copper nanoparticles exposure compared to control or standard.

The results of MTT assay from test sample showed different mortality rate at varying concentration. The mortality rate of mouse macrophages was found to increase with the raising of the copper nanoparticles concentration. The median cytotoxic concentration (CC50) was calculated. The $\mathrm{CC}_{50}$ value of copper nanoparticles was found to be $9.26054 \mu \mathrm{g} / \mathrm{mL}$. So, it is evident that copper nanoparticles have greater cytotoxicity compared to other metal nanoparticles (Heinlaan et al., 2008; Karlsson et al., 2009). From the results, it proposes that cellular self digestion or autophagy may be involved in copper nanoparticles induced cytotoxicity. It is conserved mechanism involved in the degradation of protein and organelles in the cytoplasm (Baehrecke, 2005) or ROS generation has been proposed as possible mechanism involved in autophagy induced by copper nanoparticles (Ahmad et al., 2010). Valko et al. (2007) and Paz-Elizur et al. (2008) reported that ROS considered as cytotoxic because the free radicals cause oxidative damage to biomolecules such as DNA, proteins and lipids through oxidative modifications. However, studies on the exact mechanism by which nanoparticles generated ROS in cells are still underway (Heinlaan et al., 2008).

Table 3.4: Cytotoxic activity of CuNPs

\begin{tabular}{llll} 
S.No. & CuNPs Conc. $(\mu \mathrm{g} / \mathrm{mL})$ & \% mortality & CC $_{50}$ \\
\hline $\mathbf{1}$ & 100 & 0.07 & \\
\hline 2. & 50 & 0.01 & \\
\hline 3. & 25 & 0.18 & 9.26054 \\
\hline 4. & 12.50 & 0.38 & \\
\hline 5. & 6.25 & 0.66 & \\
\hline 6. & 3.13 & 1.03 & \\
\hline 7. & 1.56 & 1.04 & \\
\hline
\end{tabular}




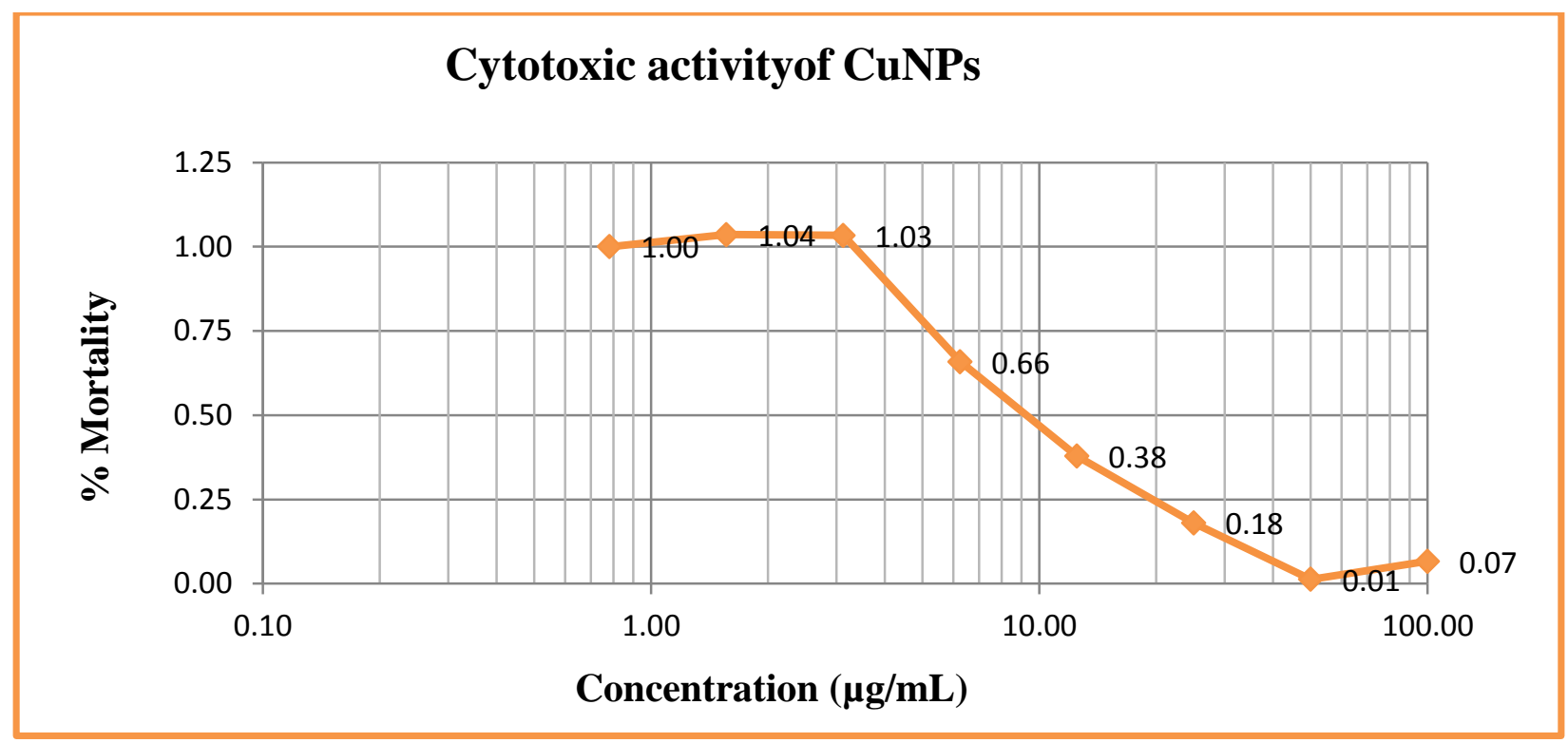

Figure 7: Showing decreasing growth rate of cell with increasing concentration of CuNPs

\section{BIOCHEMICAL STUDIES}

\section{Total Protein}

The leaves of Parthenium plant have wide range of proteins. The leaf extract was estimated for the water soluble proteins by using Lowry's method. The total protein was estimated from standard graph of protein and the leaf protein concentration was calculated. The calculated concentration was found to be $1.55 \mathrm{mg} / \mathrm{gm}$ in leaf sample of parthenium plant. Dickson et al. (2014) reported the protein content in Parthenium plant was $1.75 \%$ in Parthenium spp.

Haruna et al. (2015) observed a high level of protein (24.85\%) in the leaf of Parthenium plant and suggested that it could be used as a source of protein in animal diets therefore the level of protein in the leaf of Parthenium plant compare favorably well with some proteinous plants such as cowpeas (25\%) (Gallup and Reder, 1943), pigeon pea (20.4\%) (Jambunathan et al., 1984), lima bean, bambara groundnut (23 - 26\%) (Aletor and Aladetimi, 1989; Ene-Obong and Carnovale, 1992; Olaofe et al., 1993).

\section{Total Carbohydrate}

The leaves of Parthenium spp. contain carbohydrate, which was estimated by using total carbohydrate method (anthrone method). The calculated value obtained from the standard graph of carbohydrate was $0.3 \mathrm{mg} / \mathrm{gm}$. Haruna et al. (2015) reported that crude fiber (16.41\%) in Parthenium spp. which help to maintain the motility of food through the gut and may broken down by some bacteria in the gut to provide energy.

Feresin et al., (2000) described the antibacterial activity against Staphylococcus aureus, S. cohnii, Salmonella sp., Escherichia coli, Serratia sp., and Bacillus subtilis.

Bajwa et al., (2003) evaluated the efficacy of aqueous leaf extract of allelopathic weed, Parthenium against pathogenic fungi Drechslera tetramera, Aspergillus niger and Phoma glomerata.

Tapwal et al., (2011) demostrated the antifungal activity of aqueous extract of $P$. hysterophorus against Alternaria solani, A. zinniae, Curvularia lunata, Rhizoctonia solani and Fusarium oxysporum.

Ahmed et al., (2016) reported that DNA isolation from the weed $P$. hysterophorus is complicated due to the presence of high amount of allelochemicals in the form of secondary metabolites that causes hindrance in extraction and enzymatic reactions.

Patel, S. (2011) demonstrated that parthenin obtained from $P$. hysterophorus is known for its allelophatic properties and for being the most toxic constituent of the plant.

Swaminathan et al., (1990), Auld and Medd, (1987) confirmed that the allelopathic potential of parthenium weed results from the release of phytotoxic substances such as, ferulic, caffeic, vanillic, chlorogenic, p-coumaric and p-hydroxybenzoic acids, parthenin, ambrosin and coronopilin, which inhibit the germination and growth of several crop plants and multi-purpose trees and also cause allergic eczematous contact dermatitis and respiratory problems in humans and livestock.

Singh et al., (2001) described some of the important weeds exhibiting allelopathy and crop losses including $P$. hysterophorus. Kaur et al., (2014) reviewed the effects and management of $P$.hysterophorus. 


\section{Antimicrobial, Antioxidant and Cytotoxic Activity of Green Synthesized Copper Nanoparticle of Parthenium Hysterophorus L.}

Chung et al., (2016) reported the development of a method to synthesised copper nanoparticles by using copper acetate and leaf extract of Eclipta prostrata. Copper nanoparticles were characterized by XRD and FTIR.

Hase et al., (2016) published that Nanothechnology has wide application in various fields including Medical field. Copper nanoparticles from Leucas chinensis L. synthesized by green chemistry have shown antipyretics, antibacterial, antioxidant and antifungal activity. This process is environment friendly and non-toxic.

Thandapani et al., (2017) established the enhanced larvicidal, antibacterial, and photo catalytic efficacy of TiO2 nano hybrids green synthesized using the aqueous leaf extract of $P$. hysterophorus.

Anwar et al., (2015) confirmed the in vitro antibacterial activity of Ag nanoparticles synthesized from leaf extract of $P$. hystrophorus L.

Rajiv et al., (2013) described the bio-fabrication of zinc oxide nanoparticles using leaf extract of $P$. hysterophorus $L$. and its sizedependent antifungal activity against plant fungal pathogens.

Kaur et al., (2017) demonstrated the phenological behaviour of $P$. hysterophorus in response to climatic variations of Chandigarh, India according to the extended BBCH scale.

Navie et al., (1996) reported that Parthinium represented high genetic variability and have high invasive potential which is confirmed by statistical analysis.

Pandey et al., (2003) and Chen et al., (2010) evidenced that Parthenium reproduces generally by intra specific hybridization (cross pollination) and its pollens spread by amphibious mode of pollination which is the source of increased heterogeneity.

Jabeen et al., (2015) conducted a study to determine the genetic structure of 95 individual samples from 11 populations (9 from Pakistan and 2 from Australia) of Parthenium using ISSR fingerprinting and results demonstrated that weed in Pakistan is genetically heterogeneous and may have been the result of multiple introductions.

\section{CONCLUSION}

The current study describes a method for the biological synthesis of copper nanoparticles from weed, Parthenium hysterophorus, which is rapid, simple, efficient, environmental friendly and non hazardous. We reported here the excellent inhibitory potential of the CuNPs against test microbial strains which are considered to be significant pharmacological targets for the treatment of such microbial infections. The potency of the biogenic copper nanoparticles for radical scavenging may be used in cosmetics to prevent aging symptoms. MTT analysis indicated that copper nanoparticles are effective against the J744 A.1 cell lines, which concluded that copper nanoparticles may use in the treatment of parasitic infections.

\section{BIBLIOGRAPHY}

1) Gnanavel, I. \& Natarajan, S.K. (2013) Parthenium hysterophorus L.: A Major Threat to Natural and Agro Eco-systems in India. International Journal of Agriculture, environment \& Biotechnology, 6(2): 261-269.

2) Kaur, M., Aggarwal, N.K., Kumar, V. \& Dhiman, R. (2014) Effects and Management of Parthenium hysterophorus: A Weed of Global Significance. International Scholarly Research Notices, Article ID 368647, 12 pages.

3) Patel, S. (2011) Harmful and beneficial aspects of Parthenium hysterophorus: an update 3 Biotech. 1(1): 1-9. Published online 2011 Apr 27. doi: 10.1007/s13205-011-0007-7

4) Sushilkumar. (2014) Spread, menace and management of Parthenium. Indian Journal of Weed. Science, 46(3): $205-219$.

5) Tapwal,A., Nisha, Garg, S., Gautam, N. \& Kumar, R. (2011) In Vitro Antifungal Potency of Plant Extracts Against Five Phytopathogens. Brazilian Archives of Biology and Technology. 6(54),1093-1098.

6) Kumar, S., Chashoo, G., Saxena, A.K., Pandey, A.K. (2013) Parthenium hysterophorus: a probable source of anticancer, antioxidantandant i-HIVagents. Biomed.Res., Int. 1-11.

7) Mersie, W. \& Singh, M. (1988) Effect of phenolic acids and ragweed Parthenium (Parthenium hysterophorus L.) extracts on tomato (Lycoperscion esculentum) Growth and Nutrient and chlorophyll content. Weed Science, 36: 278-281.

8) Shehzad, M. Hussain, S., Mubeen, K., Shoaib, M., Sarwar, N., Javeed, H.M.R., Ahmad, A., \& Khalid, S. (2016) Allelopathic Effect of Santa Maria (Parthenium hysterophrous) Mulch on Growth and Yield of Soybean (Glycine max). Planta daninha, 34(4).

9) Maharjan, S., Shrestha, B.B., Jha, P.K., \& Academy, R.M. (2007) Allelopathic effects of aqueous extract of leaves of Parthenium hysterophorus L. on seedling growth of some cultivated and wild herbaceous species. Scientific World 5, 3339. 10. Ge, Y., Priester J. H., Van De Werfhorst, L. C., Walker, S. L., Nisbet, R. M. \& An, Y. J. (2014) Soybean plants modify metal oxide nanoparticle effects on soil bacterial communities. Environ. Sci. Technol. 48, 13489-13496. 


\section{Antimicrobial, Antioxidant and Cytotoxic Activity of Green Synthesized Copper Nanoparticle of Parthenium Hysterophorus L.}

10) Niraimathi, K. L., Sudha, V., Lavanya, R.,\& Brindha, P. (2013) Biosynthesis of silver nanoparticles using Alternanthera sessilis (Linn.) extract and their antimicrobial, antioxidant activities. Colloids Surf. B, Biointerfaces, 102 (2013), pp. 288291

11) Callaway, R.M. \& Aschehoug, E.T. (2000) Invasive plants versus their new and old neighbors: a mechanism for exotic invasion. Science. 290: 521-523.

12) Feresin, G.E., Tapia, A. A.\& Bustos, D.A.(2000). Antibacterial activity of some medicinal plants from SanJuan, Argentina. Fitoterapia, 71,429-432.

13) Bajwa, R., Khalid, A., Tabinda,\& Cheema, S. (2003) Antifungal activity of allelopathic plant extract III: Growth response of some pathogenic fungi to aqueous extract of parthenium hysterophorus. Pakistan Journal of Plant Pathology 2(3): 145146, 2003

14) Ahmad, J., Ibrahim, M.M., Baif. A., \& Qureshi. M. I. (2016) Standardization of DNA extraction from invasive alien weed Parthenium hysterophorus African Journal of Biotechnology, 15(22), 1035-1040.

15) Patel,S.,(2011) Harmful and beneficial aspects of Parthenium hysterophorus: an update.

16) Raghu, J.D., Veerashekar,T., Kuppast,I.J., Dharshan,S. \&,Ravi,M.C.(2014). A review on Parthenium hysterophorus Linn. Int.J.Univ.Pharm.BioSci.3,110-120.

17) Swaminathan, C., Rai, R.S.V. \& Sureshi, K.K. (1990) Allelopathic effects of Parthenium hysterophorus L. on germination and seedling growth of a few multipurpose trees and arable crops. The International Tree Crops Journal. 6: 143-150

18) Auld, B.A. \& R.W. Medd (1987) Weeds, an illustrated botanical guide to the weeds of Australia. Inkata Press, MelbourneSydney 255 pp.

19) Singh, H.P., Kohli, R.K.,\& Batish, D.R. (2001) Allelopathy in agro-ecosystems: an overview. J. Crop Prod. 4, 1-41.

20) Chung, M., Rahuman, A.A., Marimuthu, S., Kirthi, A.V. Anbarasan,K., Padmini,P., \& Rajakumar,G.(,2017) Green synthesis of copper nanoparticles using Eclipta prostrata leaves extract and their antioxidant and cytotoxic activities Exp Ther Med 2017 Jul; 14(1): 18-24.

21) Hase.G.J., Bharati,K.T., Deshmukh,K.K., Phatangre,N.D, Rahane,A., Dokhe,S.,(2016) EUROPEAN JOURNAL OF PHARMACEUTICAL AND MEDICAL RESEARCH ejpmr, 2016,3(5), 241-242

22) Thandapani, K., Kathiravan, M., Namasivayam, E., Padiksan, I.A., Natesan, G., Tiwari, M., Giovanni \& B., Perumal, V. (2017) Enhanced larvicidal, antibacterial, and photocatalytic efficacy of $\mathrm{TiO} 2$ nanohybrids green synthesized using the aqueous leaf extract of Parthenium hysterophorus. Environ Sci Pollut Res Int.

23) Anwar, M.F., Yadav, D., Kapoor, S., Chander, J. \& Samim, M. (2015) Comparison of antibacterial activity of Ag nanoparticles synthesized from leaf extract of Parthenium hystrophorus $L$ in aqueous media and Gentamicin sulphate: invitroDrug Development and Industrial Pharmacy 41(1).

24) Rajiv, P., Rajeshwari, S., \& Venckatesh, R. (2013) Bio-fabrication of zinc oxide nanoparticles using leaf extract of Parthenium hysterophorus $L$. and its size-dependent antifungal activity against plant fungal pathogens. Spectrochim Acta A Mol Biomol Spectrosc.112:384-7.

25) Kaur, A., Batish, D.R., Kaur, S., Singh, H.P. \& Kohli, R.K. (2017) Phenological behaviour of Parthenium hysterophorus in response to climatic variations according to the extended BBCH scale. Ann Appl Biol, 171: 316-326.

26) Navie, S.C., McFadyen, R.E., Panetta, F.D. \& Adkins, S.W. (1996) The Biology of Australian Weeds -Parthenium hysterophorus L. Plant Protection Quaterly 11(2):75-88.

27) Chen, S.B., Ding,W.Y., Qiu, J.B., Wang, G.Y., Zhou, Z.M., Chen, J.F., Al, W.M., Wang, C.Y. \& Xie, Q.L. (2010) The genetic diversity of the Mangrove Kandelia obovata in China revealed by ISSR analysis. Pak. J. Bot., 42: 3755-3764.

28) Jabeen, R., P. Prentis, T. Anjum \& S.W. Adkins (2015) Genetic structure of invasive weed Parthenium hysterophorus in Australia and Pakistan. Int. J. Agric. Biol., 17: 327-333.

29) Kulkarni, V.D. \& Kulkarni, P. S. (2013) Green synthesis of copper nanoparticles using Ocimum. Int. J. Chemi. Stud., 1(3):14.

30) Datta, S. \& Saxena, D.B., (2001) Pesticidal properties of parthenin (from Parthenium hysterophorus) and related Compounds. Pest Manag Sci. 57:95-101.

31) Kirby, W.M.M., Bauer, A.W., Sherris, J.C. \& Turck, M. (1966) Antibiotic susceptibility testing by a standardized single disk method. Amer. J. Clin. Pathol., 45 (6):493.

32) Tempone, A.G., Treiger Borborema, S.E., de Andrade, Jr. H.F., de Amorim Gualda, N.C., Yogi, A., Salerno Carvalho, C., Bachiega, D., Lupo, F.N., Bonotto, S.V., Fischer, D.C.H. (2005) Antiprotozoal activity of Brazilian plant extracts from isoquinoline alkaloid-producing families. Phytomedicine 12: 382-390. 


\section{Antimicrobial, Antioxidant and Cytotoxic Activity of Green Synthesized Copper Nanoparticle of Parthenium Hysterophorus L.}

33) Melville, G.W., Siegler, J.C. \& Marshall, P.W.M. (2017). The effects of d-aspartic acid supplementation in resistancetrained men over a three month training period: A randomised controlled trial. PLOS ONE 12(8): e0182630. https://doi.org/10.1371/journal.pone.0182630

34) Doyle, J.J. (1991) DNA protocols for plants. In: G. Hewitt, A.W.B. Johnson, and J.P.W. Young (eds.), Molecular Techniques in Taxonomy. NATO ASI Series H, Cell Biology, 57: 283-29.

35) Welsh, J. \& McClelland, M. (1990) FingerprlntIng genomes usIng PCR with arbitrary primers. Nucl Acids Res., $187213-$ 7218.

36) Williams, J. G. K, Kubelk, A. R., Livak, K. J. , Rafalski, J. A. \& Tingey, S. V. (1990) DNA polymorphism amplified by arbitrary primers are useful as genetic markers. Nuclic Acids Res. 18: 6531-6535.

37) Sneath, P.H.A. \& Sokal, R. R. (1963) Numeric taxonomy: the principles and practice of numerical classification.

38) Pandey, H.P. (2013). A comprehensive approach to the phenological modelling and phenoformulation of plants. Bioherald 3(1): June 2013 pp. 41- 46.

39) Achola, KJ, et al. (1998). Bronchodilating and uterine activities of Ageratum conyzoides extract. Pharmaceutical Biology, 36(2):93-96.

40) Adiguzel, A., Gulluce, M., Sengul, M., Ogutcu, Sahin, F. and Karaman, I. (2005). Antimicrobial effect of Ocimum basillicum (Labiatae) extract. Turk.J. Biol, 29:156-160.

41) Ahamed, M., Akhtar, M.J., Siddiqui, M.A., Ahmad, J., Musarrat, J., Al-Khedhairy, A.A., Al-Salhi, M.S. and Alrokayan, S.A. (2011). Oxidative stress mediated apoptosis is induced by nickel ferrite nanoparticles in cultured a549 cells. Toxico., 283: 101-118.

42) Ahamed, M., Siddiqui, M.A., Akhtar, M.J., Ahmad, I., Pant, A.B. and Alhadlaq, H.A. (2010). Genotoxic potential of copper oxide nanoparticles in human lung epithelial cells. Biochem Biophys Res Commun, 396:578-583.

43) Akhtar, M.S., Ali, M.M. and Mir, S.R. (2006). Chemical composition of essential oil of Lantana indica Roxb. leaves. J. Essential Oil Res., 18:611-612.

44) Aletor, V.A. and Aladetimi, O.O. (1989). Compositional evaluation of some cowpea varieties and some underuti-lized edible legumes in Nigeria. Die Nahru.,33:999-1007.

45) An, K. and Somerjai, G.A. (2012). Size and shape control of metal nanoparticles for reaction selectivity in catalysis. Chem Cat Chem., 4: 1512-1524.

46) ASTM (2008). Antimicrobial Susceptibility Testing Method: Time-kill test protocol. ASTM 2315(03):3.

47) Atkin, S. (2004) In: The Families and Genera of Vascular Plants.(Ed.): J.W. Kadercit. Flowering Plants Dicotyledons lamiales. Spri--Ver, Berlin, 7:461.

48) Baehrecke EH (2005). Autophagy: Dual roles in life and death. Nat Rev Mol Cell,6:505-510.

49) Barillet $S$, Jugan $M L$, Laye $M$, Leconte $Y$, Herlin-Boime $N$, Reynaud $C$, (2010). In vitro evaluation of sic nanoparticles impact on A549 pulmonary cells: Cyto-genotoxicity and oxidative stress. Toxicol Lett.; 198:324-330.

50) Bedford, E.E., Spadavecchia, J., Pradier, C.M. and Gu, F.X. (2012). Surface plasmon resonance biosensors incorporating gold nanoparticles. Macromol Biosci.,12:724-739.

51) Blois, M.S. (1958). Antioxidant determination by the use of a stable free radical. Nat., 187(4617): 1199-1200.

52) Chandran, S.P., Chaudhary, M., Pasricha, R., Ahmad, A. and Sastry, M. (2006). Synthesis of gold nanotriangles and silver nanoparticles using aloe vera plant extract. Biotechnol. Prog., 23:577-583.

53) Chin, Y.W., Balunas, M.J., Chai, H.B. and Kinghorn, A.D. (2006). Drug discovery from natural sources. AAPS Journal, 8: 239253.

54) Cui, Y., Liu, B., Xie, J., Xu, P., Habte-Tsion, H.M. and Zhang, Y. (2014). The effect of emodin on cytotoxicity, apoptosis and antioxidant capacity in the hepatic cells of grass carp (Ctenopharyngodon idellus).Fish Shellfish. Immunol, 38:74-79.

55) Curtis, A.C., Duff, D.G., Edwards, P.P., Jefferson, D.A., Johnson Kirkland, A.I. and Wallace, A.S. (1998). J. Phys Chem., 92:2211.

56) Dan, X.M., Zhang, T.W., Li, Y.W. and Li, A.X. (2013). Immune responses and immune-related gene expression profile in orange-spotted grouper after immunization with cryptocaryon irritans vaccine. Fish Shellfish Immunol., 34:885-891.

57) Dharamaraj,N., Viswanathamurthi, P. and Natarajan, K. (2001) Ruthenium (II) complexes containing bidentate Schiff bases and their antifungal activity. Trans. Met. Chem., 26:105-109.

58) Dickson, R.A., Amponash, I. K., Annan, K. and Fleischer, T.C. (2014). Nutritive potential of a polyherbal preparartion from some selected Ghanaian Herbs. J.Nat.Prod.Plant Resour., 4(3):77-81. 


\section{Antimicrobial, Antioxidant and Cytotoxic Activity of Green Synthesized Copper Nanoparticle of Parthenium Hysterophorus L.}

59) Doane, T.L. and Burda, C. (2012). The unique role of nanoparticles in nanomedicine: imaging, drug delivery and therapy, Chem Soc. Rev., 41: 2885-2911.

60) Du L, S.S., Wang, G., Jia, H., Liu, K.J., Zhao, B. (2013). Mechanism and cellular kinetic studies of the enhancement of antioxidant activity by using surface-functionalized gold nanoparticles. Chem Eur J,19: 1281-1287.

61) Du L, S.S., Wang, G., Jia, H., Liu, K.J., Zhao, B., et al (2013). Mechanism and cellular kinetic studies of the enhancement of antioxidant activity by using surface-functionalized gold nanoparticles. Chem Eur J,19: 1281-1287.

62) Ene-Obong, H.N. and Carnovale, E. (1992). A comparison of the proximate, mineral and amino acid composition of some known and lesser known legumes in Nige-ria. Food Chem.,43:169-175.

63) Gallup, W.D. and Reder, R.E. (1943). Sprouted cowpea as a source of protein and vitamins. Oklahoma Agricultural Experiment, Station, Stillwater. Academy of Science,1943:33-56.

64) Geethalakshmi, R. and Sarada, D.V. (2012). Gold and silver nanoparticles from Trianthema decandra; synthesis, chararcterization and antimicrobial properties. Int.J.Nanomedicine, 7:5378-5384.

65) Haruna, S.S., Ahmad, O. and Titilayo, J.O. (2015). Nutritional and anti-nutritional composition of Parthenium leaf. J. Invest Biochem., 4(2):58-60.

66) He, Y., Du Z., Lv, H., Jia, Q., Tang, Z., Zheng, X., Zhang K. and Zhoa F. (2013). Green synthesis of silver nanoparticles by Crysanthemun morifolium Raman extract and their application in clinical ultrasound gel. Int J. Nanomedicine., 8: 18091815.

67) Heinlaan M, Ivask A, Blinova I, Dubourguier HC, Kahru A (2008) Toxicity of nanosized and bulk ZnO, CuO and TiO2 to bacteria Vibrio fischeri and crustaceans Daphnia magna and Thamnocephalus platyurus. Chemo., 71:1308-1316.

68) Jambunathan, R., Singh, U. and Subramani, V. (1984).Grain quality of sorghom, pearl millet, pigeon pea and chicken pea. International Crops Research Institute for semi-arid Tropics, Pat., India: 1:67-89.

69) Javidiqbalpandith (2011). Antifungal activity and phytochemical screening of Parthenium species from northern Indi., World J. Pharm \& Pharma. Sci., 1(2):810-819.

70) Karlsson HL, Gustafsson J, Cronholm P, Moller L (2009) Size-dependent toxicity of metal oxide particles-a comparison between nano- and micrometer size. Toxicol Lett., 188: 112-118.

71) Kirby, W.M.M., Bauer, A.W., Sherris, J.C. and Turck, M. (1966). Antibiotic susceptibility testing by a standardized single disk method. Amer. J. Clin. Pathol., 45 (6):493.

72) Koleva, I.I, Beek, T.A.V, et al. (2002).Screening of Plant Extracts for Antioxidant Activity: a Comparative Study on Three Testing Methods. Phytochemical analysis, 13:8-17.

73) Kulkarni, V.D. and Kulkarni, P. S. (2013). Green synthesis of copper nanoparticles using Ocimum. Int. J. Chemi. Stud., 1(3):1-4.

74) Kumar, B., Smita, K., Cumbal, L. and Debut, A. (2016). Fiscus carica (Fig) fruit mediated green synthesis of silver nanoparticles and its antioxidant activity: a comparison of thermal and ultrasonication approach. Bio Nano Sci., 6:15-21.

75) Lowry, O.H., Rosebrough, N.J., Farr, L.A. and Randall, R.J. (1951). Protein measurement with the folin phenol reagent. J. Biologi. Chem., 193:265-275.

76) Luo, C., Zhang, Y. and Wang, Y. (2005). Palladium nanoparticles in poly (ethyleneglycol): the efficient and recyclable catalyst for Heck reaction. J. of Mol Catalysis A: Chemical. 229 (1-2): 7-12.

77) Manda, R.M. and Seru, G. (2015). Evaluation of Parthenium hysterophous for antiulcer activity in experimental Rat, Int. J. Pharm Bio Sci., 5(1):01-04.

78) Mittle, A.K., Kumar, B.S. and Banerjee, U.C. (2014). Biosynthesis of silver nanoparticles: elucidation of prospective mechanism and therapeutic potential. J. Colloid Interface Sci., 415:39-47.

79) Monga, A. and Pal, B. (2015). Improved catalytic activity and surface electro-kinetics of bimetallic Au-Ag core-shell nanocomposites. New J. Chem., 39(1):304-313.

80) Morris, D. L. (1948). The qualitative determination of carbo- hydrate with Dreywood's anthrone reagent. Science, 107:254-255.

81) Mossman, T. (1983). Rapid Colorimetric Assay for Cellular Growth and Survival: Application to Proliferation and Cytotoxicity Assays. J. Immunol Methods, 65:55-63.

82) Nakache, E., Poulain, N., Candau, F., Orecchioni, A.M. and Irach, J.M. (1999) Biopolymer and polymer nanoparticles and their biomedical application In: Nalwa H.S. editor. Handbook of nanostructure material and nanotechnology. Academic Press: Yew York, 557-635. 


\section{Antimicrobial, Antioxidant and Cytotoxic Activity of Green Synthesized Copper Nanoparticle of Parthenium Hysterophorus L.}

83) Niraimathi, K.L., Sudha, V., Lavanya, R. and Brindha, P. (2013). Biosynthesis of silver nanoparticles using Alternanthera Sessilis (Linn.) extract and their antimicrobial, antioxidant activities. Colloids Surf B: Biointer., 102: 288-291.

84) Niska, K., Santos-Martinez, M.J., Radomski, M.W. and Inkielewicz-Stepniak, I. (2015). CuO nanoparticles induce apoptosis by impairing the antioxidant defense and detoxification systems in the mouse Hippocampal HT22 cell line: Protective effect of crocetin. Toxicol In Vitro, 29: 663-671.

85) Olaofe, O., Umar, Y.O. and Adediran, G.O. (1993). The effect of nematicides on the nutritive value and functional properties of cowpea seeds (Vignaunguiculata L. Walp). Food Chem., 46:337-341.

86) Patel, R.M, Patel , N.J, (2011). In vitro antioxidant activity of coumarin compounds by DPPH, superoxide and nitric oxide free radical scavenging methods. Journal of advanced pharmacy education \& research, 1:52-68.

87) Pawar, D., Shaikh, S., Shulaksana, D. and Kanawade, R. (2014). Green synthesis of copper nanoparticles using Gloriosa superbaL leaf extract, Int J. Pharm \& Pharmceu Res., 203-209.

88) Qi, Z.H., Liu, Y.F., Luo, S.W., Chen, C.X., Liu, Y. and Wang, W.N. (2013). Molecular cloning, characterization and expression analysis of tumor suppressor protein $\mathrm{p} 53$ from orange-spotted grouper, Epinephelus coioides in response to temperature stress. Fish shellfish Immunol., 35: 1466-1476.

89) Ranjitham, A.M., Suja, R., Caroling, G. and Tiwari, S. (2013). In vitro evaluation of antioxidant, antimicrobial, anticancer activities and characterization of Brassica Oleracea. Var. Bortrytis. L Synthesized Silver nanoparticles. Int J Pharm Pharm Sci., 5(4): 239-251.

90) Sasidharan, S., Chen, Y., Sarvanam, K., Sundram, K.M. and Yoga, Latha L. (2011). Extraction, Isolation and Characterization of Bioactive Compounds from Plants extracts, Afr. J. Tradit. Complement Altern. Med., 8:1-10.

91) Song, J.Y. and Kim, B.S. (2009). Rapid biological synthesis of silver nanoparticles using plant extracts. Bioprocess Biosyst Eng., 32:79-84.

92) Sujitha, M.V. and Kannan, S. (2013). Green synthesis of gold nanoparticles using citrus fruits (Citrus lemon, Citrus reticulates and Citrus sinesis) aqueous extract and its characterization. Spectrochim Acta A.Mol Biomol Spectrosci., 102:15-23.

93) Swarnalatha, Y., Krishnan, D. and Rajasekar, S.P.V. (2013). Antibacterial activity of biogenic silver nanoparticles from Sphaeranthus amaranthoides. Int J.Pharm Sci., 5(4):594-596.

94) Tilaki, R.M., Irajizad, A. and Mahadevi, S.M. (2007). Appli. Phys., A88:415.

95) Valko M, Leibfritz D, Moncol J, Cronin M, Mazur M, Telser J. (2007). Free radicals and antioxidants in normal physiological functions and human disease. Int J Biochem Cell Biol., 39: 44-84.

96) Vera, L.M. and Migaud, H. (2009). Continuous high light intensity can induce retinal degeneration in Atlantic salmon, Atlantic cod and European sea bass. Aq.cult., 296: 150-158 